\title{
The Ira Ara site: A fortified settlement and burial complex in Timor-Leste
}

\author{
Peter V. Lape, John Krigbaum, Jana Futch, Amy Jordan \\ and Emily Peterson
}

\section{Introduction}

Much of the archaeological research to date conducted in Timor-Leste has focused on Pleistocene and early Holocene sites with an orientation toward questions of initial human settlement and migration (e.g. O'Connor 2007; O'Connor et al. 2002) or the rich rock art record in the region (Lape et al. 2007; O'Connor 2003; O'Connor and Oliveira 2007). Recently there has been a growing interest in investigating the many fortified and/or hilltop settlements that date to the post-AD 1000 era (Chao 2008; Lape 2006; Lape and Chao 2008). These are of interest because of the prominent role they play in contemporary Timorese concepts of history, sacred practice, land tenure and identity, as well as the potential they hold to understand past social conflict and landscape use. This latter issue resonates with the recent history of violent conflict in Timor-Leste as well as current struggles to resolve land tenure and land use by contemporary Timorese individuals and institutions (Fitzpatrick 2002, 2010; Pannell 2006; McWilliam 2008).

Although archaeological research on these sites is still in its formative stages, having commenced only since 2003, attempts have been made to explain the chronological and spatial patterns of fortified sites. A model proposed by Lape and Chao (2008) predicts that initial fortification building in a given region will be located at the boundaries of resource-rich and resourcepoor areas during times of drought. According to the model, these initial fortified settlements should have appeared when drought frequency and severity increased significantly, such as when El Niño-related droughts affected Timor. Thus, the model predicts that the earliest fortifications will appear in these areas during the twelfth to fourteenth centuries AD, when El Niño Southern Oscillation frequency doubled (compared with previous centuries). Fortification building after this initial resource-triggered phase may be caused by other reasons related to social processes, and the model does not predict the timing and location of these activities. Preliminary tests of this model on dated fortified sites in the Lautem and Manatuto districts of Timor-Leste were supportive. Investigations of this pattern based on the published literature in the wider tropical Pacific region did not strongly confirm the theory (Field and Lape 2010). However, more work is needed to test the model in Timor-Leste and other regions. Well-dated sites, particularly of the initial wall construction, are a crucial requirement for this line of investigation.

The Ira Ara site is located adjacent to a regionally important permanent freshwater spring, which should have flowed even during times of severe drought. According to the model, the Ira Ara area should show a higher than average concentration of fortified sites, the oldest of 
which should date to the twelfth to fourteenth century AD. Unfortunately, we were not able to definitely date the initial construction of the walling at Ira Ara, and so this site cannot be used as an additional test of the Lape and Chao (2008) model without additional excavation and dating. However, the site is of interest because of the human burials contained in it. Two of these burials were partially excavated and will be discussed in this paper. These are the only burials excavated and analysed from Timor-Leste to date and they provide an initial glimpse into late precolonial burial practices that include an analysis of associated grave goods and insight into past diet using human bone chemistry.

\section{Site description}

Ira Ara is the name of a small settlement located in the Lautem district of eastern Timor-Leste (Figure 3.1). The name (literally 'water source' or 'water roots' in the Fataluku language, a nonAustronesian language spoken in the Lautem district) refers to a large freshwater spring and an associated $t e i$, or spirit dweller, around which the village is organised. Just to the north of the spring pool is a large circular mound approximately $60 \mathrm{~m}$ in diameter. The mound consists of a limestone outcrop that has been built up and expanded by humans with dry stacked limestone boulders and sediment fill to create a roughly circular walled platform about $3 \mathrm{~m}$ higher than the natural surface on the south and west sides. The north and east sides of the outcrop are unmodified cliffs, the tops of which extend about $6-10 \mathrm{~m}$ above the surrounding landform, which slopes down to the sea. We located the site in a 2004 survey of water sources in the Lautem area. At that time, the south and west stone walls and fill were being dug away by local residents to provide material for terracing around a small church and chapel just west of the spring (Figure 3.2). We recorded fragments of human bone in the scattered fill and in situ exposures of graves in these cut sections of the mound. On top of the mound were several stone platforms similar in size and construction to graves in Tutuala area fortified sites. Part of one of the platforms on the southern edge of the mound was probably carried away during the recent wall deconstruction. Local residents were aware that their digging was exposing and disturbing graves. They reported that prior to 1999, Indonesian authorities had forced them to build the church and chapel using stone and fill from the site. It is unclear whether these activities continued after Indonesian withdrawal in 1999.

In 2005, we returned with a small University of Washington field school and asked for permission to excavate in non-burial portions of the mound and in the area associated with the previously disturbed burials. Local permissions were complicated by the fact that seven ratu (clan) territories converged on the mound and the boundaries were unclear in the area of the graves. Over the course of two weeks of excavations, permissions were granted and revoked several times as different clan leaders were consulted and boundaries re-evaluated. Ultimately we were able to designate three formal units (Figure 3.1) and partly excavated a $50 \mathrm{~cm} \times 2 \mathrm{~m}$ pit in a non-burial area of the mound (Unit 1) plus portions of two disturbed burials (Unit 2, Burial 1 and Unit 3, Burial 2). 


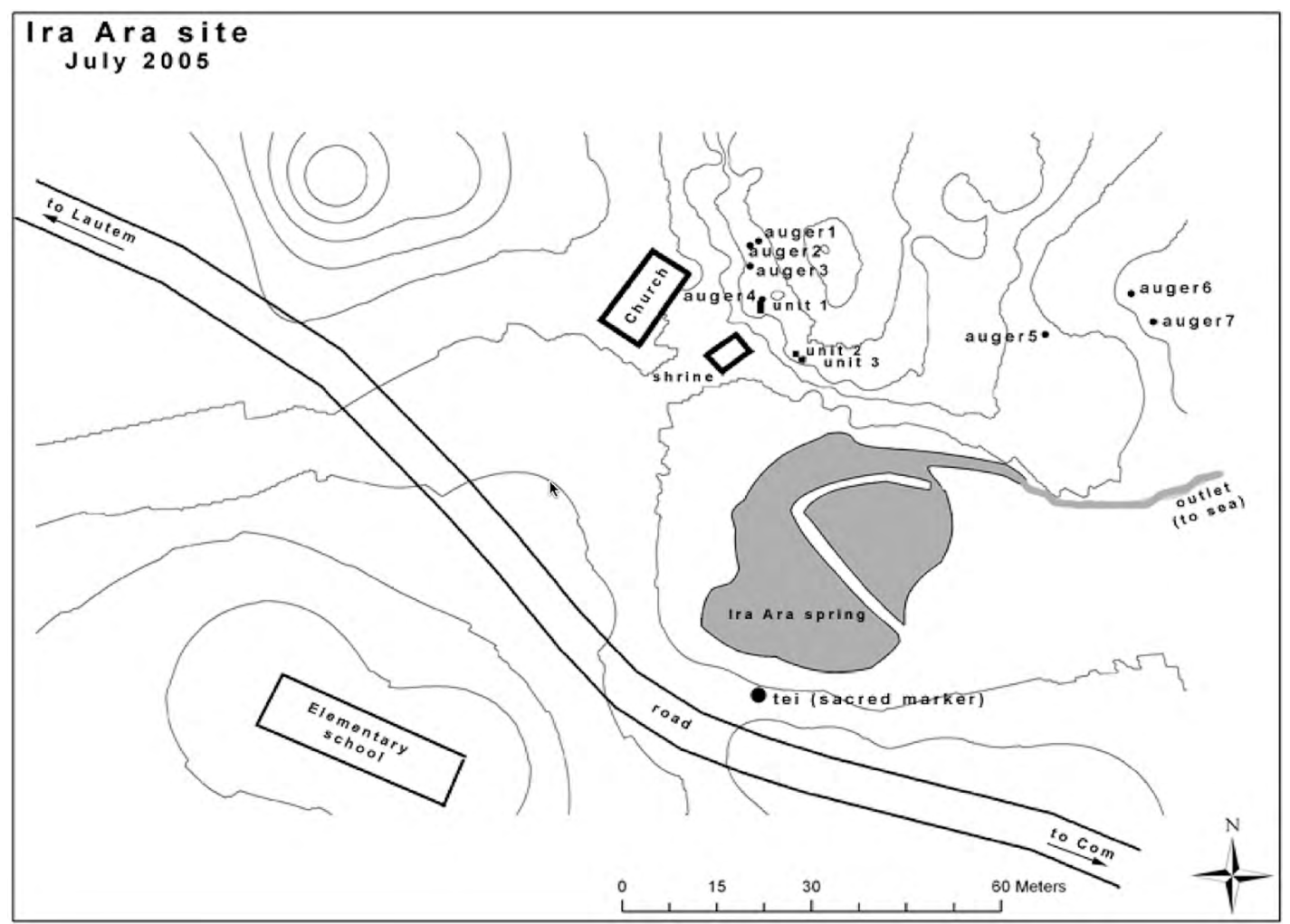

Figure 3.1. Map of the Ira Ara site.

Source: Peter V. Lape.

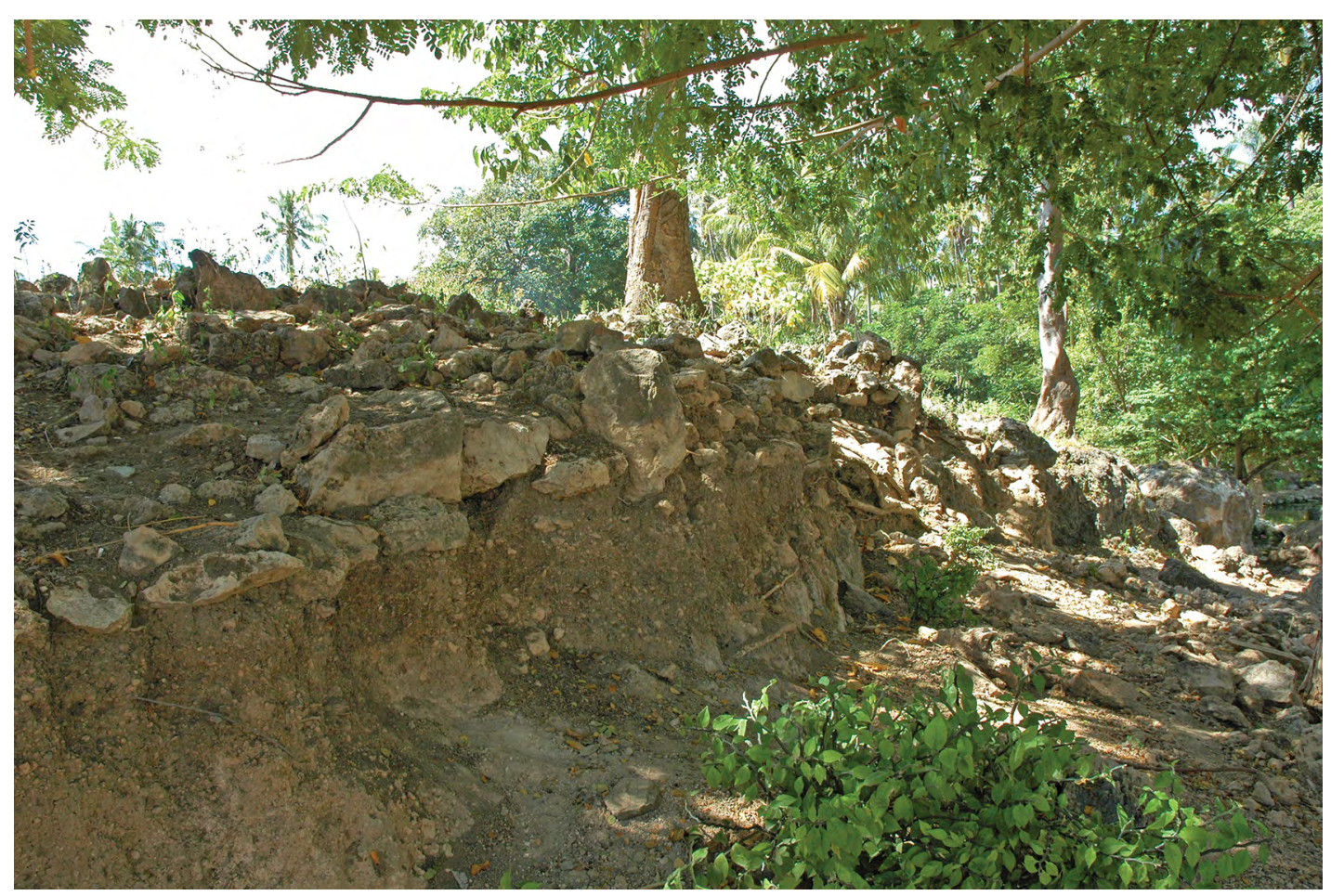

Figure 3.2. Ira Ara south mound edge showing disturbed section, July 2005.

Source: Photo courtesy of jana Futch. 
Abandoned walled village sites (lata) are places of high cultural importance in much of Lautem. They often contain the graves of ancestors, whose names are sometimes remembered by local residents (for detailed ethnographic analyses of Fataluku cultural geography, see McWilliam 2007a, 2007b, 2007c, 2008; Pannell 2006; Pannell and O'Connor 2005). Local residents remember these sites as villages once inhabited by a single or, in rare cases, multiple ratu. Previous archaeological excavations confirm that these are usually occupation sites containing a wide range of artefacts and faunal remains (Chao 2008; Lape 2006; Lape and Chao 2008). These sites are frequently associated with or enclose $t e i$, which are glossed as 'sacred' equivalent to the Tetum term lulik, but also mean 'spirit being', and are usually marked with stone or carved wood posts $(s i k u a)$. Contemporary people continue to visit tei, provide sacrificial food during ritually important events, and maintain the sikua. The Ira Ara tei is located on the south side of the spring pool and is marked by a sikua made from an upside-down tree stump with roots, symbolising the 'root' (ara) aspect of the spring (Figure 3.3). The stone burial platforms on top of the mound are known locally as grave markers, but the ancestors buried in the largely destroyed southernmost platform are thought to be from a ratu that was extirpated during an inter-clan battle in the past. There are members of this ratu currently living in Ira Ara, but they are recent immigrants from another part of Lautem and not considered direct descendants of those buried in the mound. This may explain why the burial platform and the human remains under it were disturbed, and why we were ultimately allowed to excavate the remains. Under normal circumstances, burial platforms in Lautem are well maintained and disturbance of any kind (archaeological or otherwise) is prohibited.

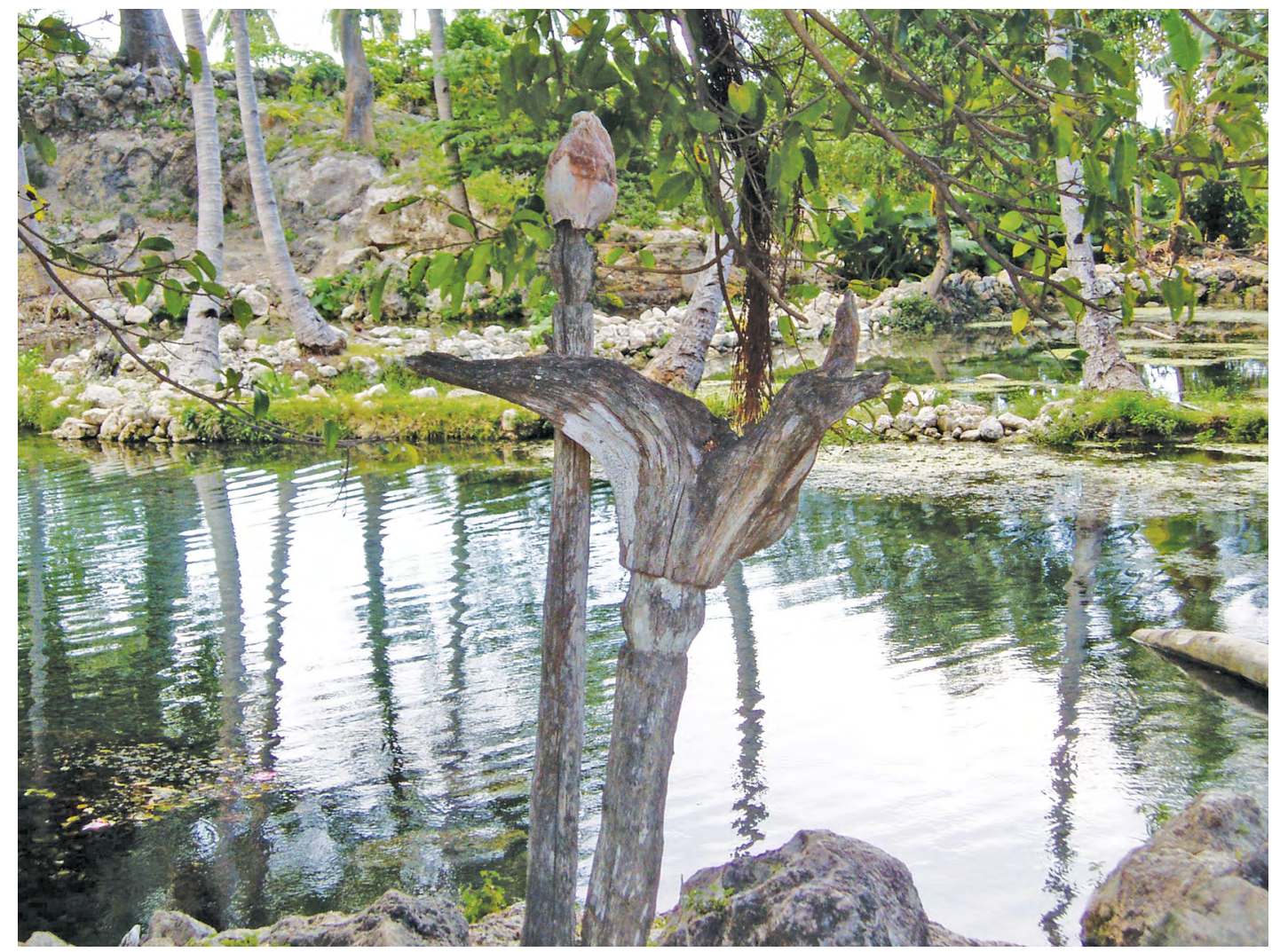

Figure 3.3. The Ira Ara sikua, with spring pool and mound in background, July 2004.

Source: Photo courtesy of Peter V. Lape. 
Given the short time frame for excavations, which was further shortened by delays during permission negotiations, our excavation strategy was focused on identifying an occupation chronology for the mound, initial wall construction date, and documentation of disturbed burials. Very shallow sediments in eastern Timor-Leste coupled with high levels of forest disturbance and erosion make it difficult to find intact, stratified deposits at open sites, so excavations were preceded by auguring to identify areas of the mound with the deepest intact fill. Unit 1, located in the non-burial portion, was excavated in the area of deepest sediments, but it still only extended to a maximum depth of $51 \mathrm{~cm}$ before hitting limestone bedrock. The entire central portion of the mound was comprised of exposed limestone devoid of sediment, with earthenware and seventeenth- to nineteenth-century tradeware sherds scattered about the rock surface. This area may have once been covered with sediment that later eroded away, leaving the denser artefacts behind, though it is also possible that there was never much sediment here. The two burials identified were located on the eroding and disturbed southern edge of the mound. We were only able to recover the cranium associated with Burial 1, and just the left portion of the upper body associated with Burial 2 from the pelvis to the cranium (Figures 3.4 and 3.5). All excavated deposits were dug with trowels and dry screened through $4 \mathrm{~mm}$ mesh. Pits were backfilled immediately after excavations and, in the case of the two burials, local residents constructed a rock retaining wall to hold backfill in the grave areas after we finished excavation. All collections were brought to the University of Washington for analysis on loan from the Ministry of Culture of Timor-Leste. Human remains (except small samples destroyed by analysis) were returned to the leader of the ratu associated with the burials in November 2006 for reburial, presumably at the same site.

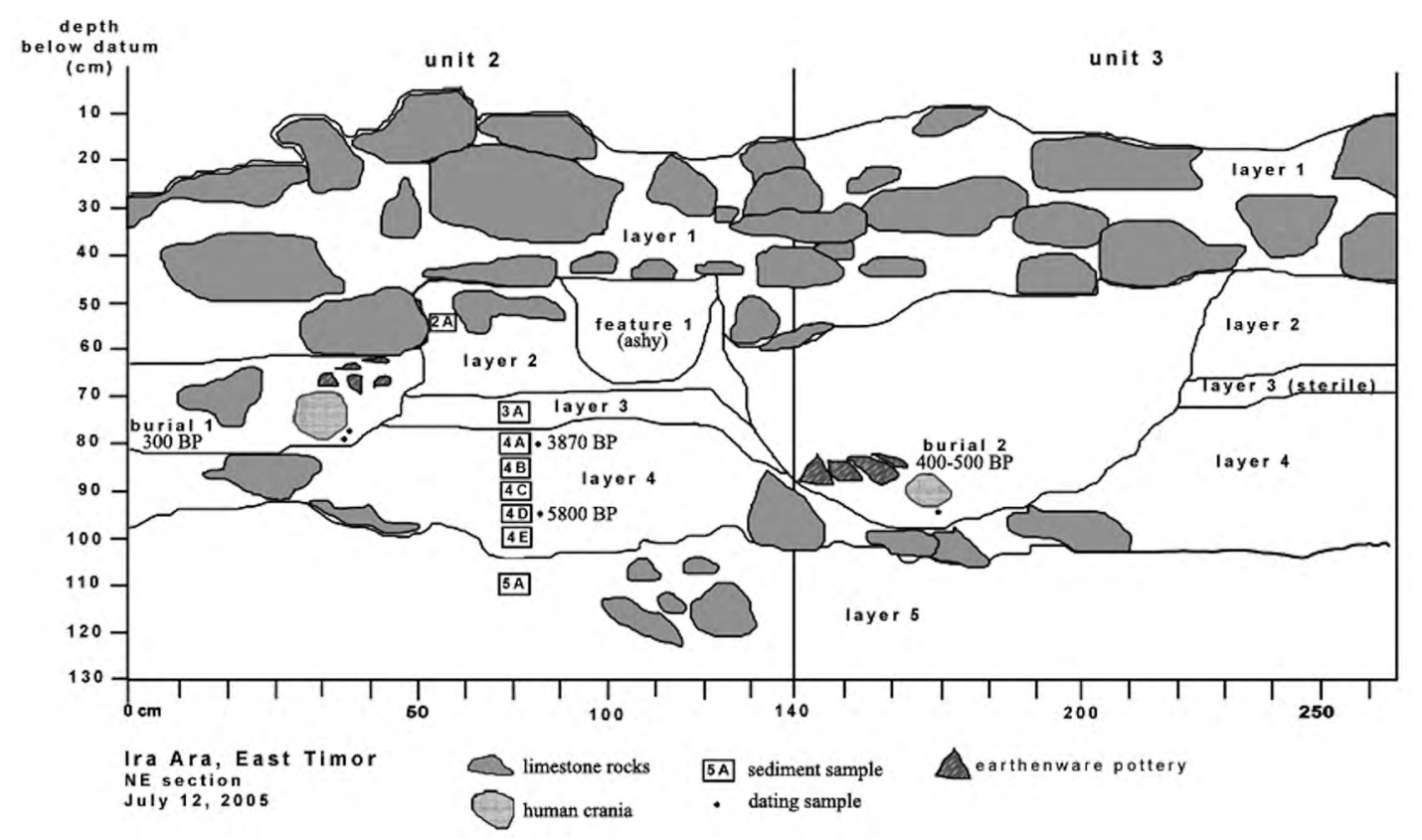

Figure 3.4. Ira Ara northeast section of Units 2 and 3 (Burials 1 and 2).

Source: Peter V. Lape. 


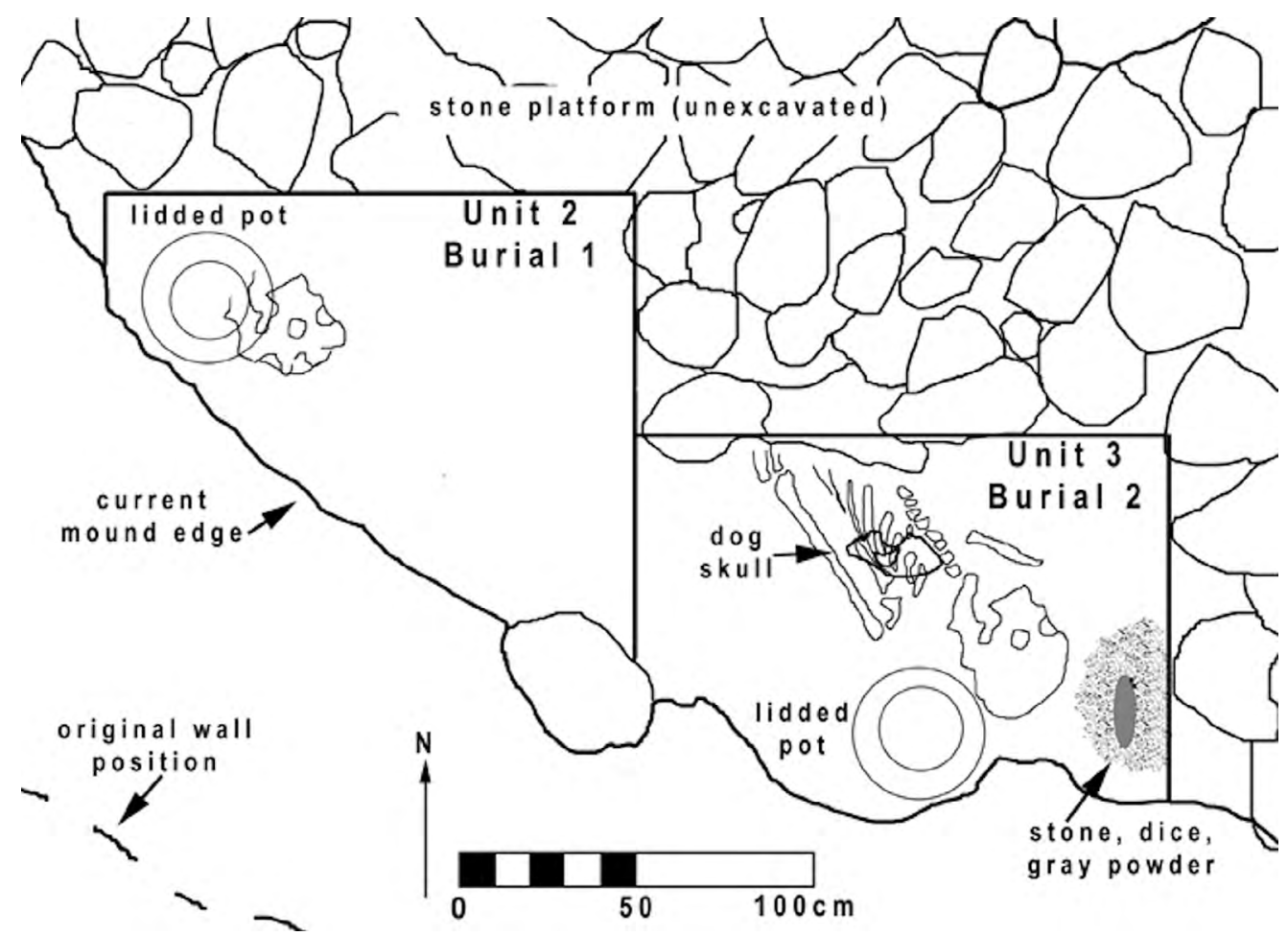

Figure 3.5. Plan view of Ira Ara Burials 1 and 2.

Source: Peter V. Lape.

\section{Site chronology}

As discussed above, precise dating of the initial construction of fortified sites is needed to test the model proposed by Lape and Chao (2008). However, shallow and disturbed sediments in fortified sites in the Lautem area have made precise dating of the construction and occupation of these sites difficult (Lape 2006). Further complicating this is the flat radiocarbon calibration curve known to exist at the time during which many of the sites were built. Unfortunately, we did not encounter well-stratified undisturbed cultural deposits at the Ira Ara site. We obtained six radiocarbon dates and two thermoluminescence dates from the Ira Ara site (Table 3.1). Six of these eight dates were from the burials that were dug after the initial wall construction and showed the best promise for dating the burials themselves. The other two dates were from undisturbed occupation layers below the burials that appear to predate the wall construction and give an indication as to pre-fortification use of the site (Figure 3.4). We did not expose stratigraphic contexts that were suitable for dating the initial wall construction. We also did not conduct any direct dating of Unit 1, as it lacked stratigraphic integrity. As part of an ongoing project to evaluate the relationship between luminescence and radiocarbon dates in the region, we paired two sets of luminescence/C14 dates from earthenware sherds with sooting on their exterior surfaces plus an additional associated charcoal C14 sample. Both of these sets of dates fell within the uncertainty range of their respective paired and associated samples. Three dates from Burial 1 all had relatively large uncertainties of \pm 200 years. Although the C14 results from Burial 2 suggest a somewhat older date compared to Burial 1, the luminescence date had a smaller uncertainty that placed it in the late seventeenth century $\mathrm{AD}$, roughly contemporaneous with Burial 1. Neither burial contained complete tradeware vessels as grave goods, although there were a small number of fragments of seventeenth-century $\mathrm{AD}$ tradeware in the burial fill also suggesting seventeenth century or later burial dates. 
Table 3.1. Radiocarbon and thermoluminescence dates from Ira Ara.

\begin{tabular}{|c|c|c|c|c|c|c|c|}
\hline $\begin{array}{l}\text { Sample } \\
\text { number }\end{array}$ & $\begin{array}{l}\text { Lab } \\
\text { number }\end{array}$ & Layer/association & Material & $\begin{array}{l}\text { Radiocarbon } \\
\text { age (BP) }\end{array}$ & $\begin{array}{l}13 C / 12 C \\
\text { ratio }\end{array}$ & $\begin{array}{l}\text { C14 } 2 \text { sigma } \\
\text { calibrated or } \\
\text { luminescence age }\end{array}$ & $\begin{array}{l}\text { Basis for } \\
\text { luminescence } \\
\text { age }\end{array}$ \\
\hline $02 B 1011004$ & \begin{tabular}{|l} 
Beta- \\
214263
\end{tabular} & $\begin{array}{l}\text { burial } 1 / \text { directly } \\
\text { under cranium }\end{array}$ & marine shell & $190+/-40$ & $+0.3 \%$ & AD 1650-1810 & - \\
\hline 02B1017001 & $\begin{array}{l}\text { Beta- } \\
214264\end{array}$ & $\begin{array}{l}\text { burial } 1 / \text { soot from } \\
\text { burial pot }\end{array}$ & charcoal & $60+/-40$ & $-24.0 \%$ & $\begin{array}{l}\text { AD 1680-1740 } \\
\text { AD 1800-1930 } \\
\text { AD 1950-1960 }\end{array}$ & - \\
\hline 022B057004 & $\begin{array}{l}\text { UW- } \\
1675 \\
\end{array}$ & $\begin{array}{l}\text { burial 1/burial pot } \\
\text { lid fragment }\end{array}$ & earthenware & - & - & AD 1630-1690 & \begin{tabular}{|l|}
$\mathrm{TL} / \mathrm{IRSL} / \mathrm{OSL}$ \\
\end{tabular} \\
\hline 03B2000037 & \begin{tabular}{|l|} 
Beta- \\
21465
\end{tabular} & $\begin{array}{l}\text { burial 2/human } \\
\text { ulna }\end{array}$ & bone & $150+/-50$ & $-12.0 \%$ & AD 1440-1650 & - \\
\hline 03B2147005 & $\begin{array}{l}\text { Beta- } \\
21466\end{array}$ & $\begin{array}{l}\text { burial 2/soot from } \\
\text { burial pot }\end{array}$ & charcoal & $300+/-40$ & $-24.2 \%$ & AD 1470-1660 & - \\
\hline 03B2147005 & $\begin{array}{l}\text { UW- } \\
1676 \\
\end{array}$ & $\begin{array}{l}\text { burial 2/burial pot } \\
\text { fragment }\end{array}$ & earthenware & - & - & AD 1390-1690 & $\mathrm{TL}$ \\
\hline 024A061900 & \begin{tabular}{|l|} 
Beta- \\
230699 \\
\end{tabular} & unit 2/layer $4 \mathrm{~A}$ & marine shell & $3870+/-40$ & $+0.8 \%$ & $2560-2360 \mathrm{BC}$ & - \\
\hline 024D091900 & $\begin{array}{l}\text { Beta- } \\
230700\end{array}$ & unit 2/layer 4D & marine shell & $5800+/-40$ & $+1.7 \%$ & $4830-4660 \mathrm{BC}$ & - \\
\hline
\end{tabular}

Source: Authors' summary.

Two C14 dates on marine shell were obtained from an exposed but undisturbed section of Layer 4 (Figure 3.4). Both burial pits cut into Layers 3 and 4, but Layer 4 appears to have been deposited prior to the wall construction layers. Thus, wall building must have happened after the deposition of Layer $4(5800-3870 \mathrm{cal} \mathrm{BP})$ and before Burial 2 (500 cal BP). It is possible that this large range could be reduced with additional excavation targeting Layer 2 in an area outside of burial disturbance.

No pottery was observed in Layer 4, even though the upper portion falls within the age when pottery is found at other sites in Timor and eastern Indonesia. However, we only cleared portions of a section and did not excavate this layer completely, so conclusions are subject to further evaluation. The date of the lower part of Layer $4(5800 \mathrm{cal} \mathrm{BP})$ suggest the site was attractive to people (probably because of the spring) prior to the so-called Southeast Asian Neolithic (4000-2000 BP), and that the site has further potential to reveal landscape use in this period (Spriggs 2000, 2003; Spriggs et al. 2003). Relatively large numbers of lithic artefacts, found in all excavation units at the site (probably redeposited from older layers by the burial disturbance or washed in from higher elevation portions of the mound), also suggest a long occupation chronology for the site, predating the seventeenth-century AD age of the burials when metal would have been widely available and lithic tool using traditions had presumably ended.

\section{Human burials}

The two burials identified in the field and partially recovered were adjacent to each other and covered by a single stone platform, the remnants of which extended north into the intact mound (Figure 3.5). The Burial 2 skeleton was extended and oriented north-south with the head to the south, away from the coastline and toward the spring pool. Based on the observed cranial position of Burial 1, this skeleton was similarly oriented. The grave pits were lined with limestone boulders. Both graves had been exposed in section from the south, and both crania were exposed when we began excavation in 2005. The Burial 1 cranium was very fragmented, probably as 
a result of recent exposure and disturbance by roots and rock boulder fill above. Associated human remains recovered from Burials 1 and 2 were studied with respect to inventory and life history parameters, including age and sex criteria, observed pathologies and stable isotope analysis. Scoring and procedures for age and sex estimation followed Bass (2005) and Buikstra and Ubelaker (1994).

\section{Burial 1 (young adult female)}

Only portions of the cranium were recovered of this individual, which included two portions of the upper jaw (maxilla) with right teeth in situ, portions of both right and left temporal bones, including the left zygoma (cheek bone), and a full complement of loose, slightly worn teeth. The right temporal fragment observed helps to identify Burial 1 as a young female and the mastoid process is slight in volume with a score of 1 (ordinal scale 1 to 5), which also suggests female, making the sex estimation of this individual quite secure, and consistent with the overall gracile nature observed in the preserved cranial fragments. The left temporal fragment lacks the mastoid process and petrous portion, but includes the squamous portion and an articulated zygoma. The squamous exhibits a fresh suture along its anterior margin (spheno-temporal suture), which suggests an age of young adulthood, probably 20-30 years. The left temporal fragment also shows evidence of pathology, with pitted and reactive bone associated along the inferior distal margin of the zygoma, at the distal site of origin of the masseter muscle. The masseter is a major chewing muscle, and this individual would have felt pain during chewing based on this observation. A curious localised, bowl-shaped wear pattern on the occlusal surface of the left upper first molar (LM1) and lower molars (LM1 and LM2) was observed in association with this feature. The LM1 and LM2 were quite heavily worn; LM3 was unworn, but exhibited a single, gross (extreme) dental caries along the distal portion of the cemento-enamel junction. Some noteworthy staining, reddish in colour, was also observed on anterior and posterior teeth of this individual that can likely be attributed to the chewing of betel nut. Staining was patchy rather than ubiquitous across the preserved dentition; however, it is informative to couple the extreme localised tooth wear with the pathology observed on the zygoma and the staining observed on portions of the dentition.

With the full complement of teeth present in this young adult female, those teeth associated with alveolar bone (principally the right maxilla (RM3-RM2; RM1-RI1), but also a small mandibular fragment (LM2)) showed no evidence of pathology. Similarly, teeth showed no signs of dental caries except for the gross caries in the LM3. Wear scores were recorded and show slight wear generally, albeit moderate wear on the molars associated with the left side of the individual's jaw. Non-metric features of the molars included the presence of a large hypocone and the absence of a metaconule, Carabelli's cusp and enamel extensions. In addition, no shovelling of the incisors was observed and all premolars had a single root.

\section{Burial 2 (young adult female)}

Burial 2 is better represented skeletally than Burial 1, with portions of the lower jaw (mandible), upper vertebrae, and left trunk and upper arm recovered during excavations. Postcranially, the upper thorax was preserved with both scapulae and clavicles represented, including the glenoid fossa of the left scapula, which articulated with a near-complete ( 95 per cent) humerus. Portions of the manubrium and the body of the sternum were also present.

The mandible was preserved in two parts, with most associated dentition present. RM3 to RI1 were in situ, LI1 to LP1 were loose, and LM2 and LM3 were in situ, in a smaller fragment. The second left premolar and first molar (LP2 and LM2) were not observed. Well-defined noncarious buccal pits were present on RM1 and LM2. All teeth scored for dental wear were lightly 
worn, and with the eruption and partial wear of the third molars, young adult age is supported. Similar to Burial 1, only one dental caries was observed with Burial 2, with her LM3, although this was of moderate size and situated on the occlusal surface of the tooth. Dental calculus was light. Remnant evidence of dental staining was present along occlusal aspects of the molars and incisors, although this too was slight to moderate in incidence.

With respect to the left scapula, five fragments were examined and a scapular notch was deemed absent. The only metric readily obtained from the gracile pieces was with the glenoid cavity, which had a vertical diameter of $35 \mathrm{~mm}$, and is in the possible female size range according to Bass (2005:123). The overall gracile character of the shoulder girdle, however, may be coupled with a metric from the near-complete right clavicle. Its maximum length was $136.5 \mathrm{~mm}$, which equates to female in Bass (2005:131), and the midshaft circumference was $35 \mathrm{~mm}$. The medial epiphysis shows complete union ( $>20$ years), and there is a pronounced conoid tubercle. The left clavicle is missing its medial end but shows evidence of a pronounced bilateral groove along the conoid tubercle. The left humerus, near complete, was measured for maximum length $(299 \mathrm{~mm})$, maximum/minimum midshaft diameter $(18.85 / 14.412 \mathrm{~mm})$, vertical humeral head diameter $(43.16 \mathrm{~mm})$, epicondylar breadth $(54.91 \mathrm{~mm})$ and articular width $(42.21 \mathrm{~mm})$. No septal aperture was present and there was a moderate bicipital groove present. The gracile nature of the limb bones, including the humeral head diameter and epicondylar breadth, and the clavicle support a female sex designation for Burial 2.

The preserved vertebrae were similarly gracile and, overall, moderately well preserved. All seven cervical vertebrae were preserved, although the axis, atlas and C7 were only represented by partial centra (bodies). Otherwise, all cervical and thoracic vertebrae $\mathrm{T} 1$ to $\mathrm{T} 8$ were represented by both centra and respective neural arches. Corresponding ribs with the preserved thoracic vertebrae include both right and left 1 st and 2 nd ribs and principally left $3 \mathrm{rd}-7$ th ribs. This is consistent with the field notes and recordings of Burial 2 in situ and subsequent recovery of her partial skeleton.

\section{Isotopic analysis}

Stable isotope ratio analysis is now routine to help situate individuals with respect to their presumed diet versus that observed from other lines of evidence in the archaeological record. Shellfish remains present in the Ira Ara site, and the site's proximity to the coast suggests that marine foods, for example, played a significant role in the local diet, as it has for over 30,000 years, as represented in eastern Timor-Leste cave assemblages (O'Connor et al. 2002; Veth et al. 2005). A pilot study examining the tooth enamel from each of the two burials was conducted to assess the nature of diet consumed by the individuals represented at the site, which has the potential to reveal other types of foods consumed by people there that are not represented in the archaeological record.

Ratios of light stable isotopes of carbon and nitrogen are especially useful in reconstructing the dietary regimes of past peoples; however, such analyses require good preservation of bone collagen. The radiocarbon date on bone collagen obtained from the bone seems to have produced a reasonable $\delta^{13} \mathrm{C}$ value $(-12.0 \%$ o) through the analysis supplied by Beta Analytic (Table 3.1). Such a value suggests that $\mathrm{C} 4$ plants (which would have principally included millet and/or sugarcane) and perhaps marine foods were major food sources. This is corroborated by bulk analyses of the tooth enamel from the two left lower third molars (LM3) from Burials 1 and 2. These two teeth were sampled for stable isotope ratio analysis of the tooth enamel. Here we focus on the $\delta^{13} \mathrm{C}$ values from analysis of cleaned 'bulk' tooth enamel, with Burial 1 averaging $-7.3 \%$ o and Burial 2 averaging $-6.4 \%$, yielding a population average of $-6.9 \%$. These $\delta^{13} \mathrm{C}_{\text {en }}$ results are not comparable directly with the $\delta^{13} \mathrm{C}_{\mathrm{co}}$ value of $-12 \%$ from the $\mathrm{C} 14$ analysis as they derive from 
different tissues. The isotope ratio derived from the bone collagen fraction is biased towards the protein portion of the diet (which has a fractionation offset from consumed 'protein' of c. 5\%). In contrast, the fractionation offset from diet for tooth enamel is closer to $-9.4 \%$ (Ambrose et al. 1997). What this translates to for the Ira Ara findings is that the maritime-based diet we are observing was clearly supplemented by $\mathrm{C} 4$ cultigens most likely millet, and not simply ${ }^{13} \mathrm{C}$ enriched through the consumption of marine-based foods. Marine foods, however, were clearly a component of the diet, and these may have included a variety of invertebrate and vertebrate foods, including perhaps higher trophic/pelagic species.

\section{Grave goods}

Burial 1 had an intact earthenware pot and lid (Figure 3.6) immediately right of the cranium, which contained sediment and the bones of a small bird, probably an immature chicken (Gallus gallus). Five brass/bronze earrings were found associated with the fragmented cranium.

Burial 2 also contained a small-lidded pot to the immediate left of the cranium, which was quite similar in size and form as that found in Burial 1, but it was fragmented and did not contain intact fill. Two unusual ivory dice and a groundstone artefact were located right of the cranium, the latter tentatively identified by local informants as a knife sharpener (Figure 3.7). A white powder, identified as calcite, was associated with the groundstone and ivory dice. It may have been related to chewing of betel nut, which is common in Ira Ara today, and may have been responsible for the staining and erosion of the teeth in both burials as described above.

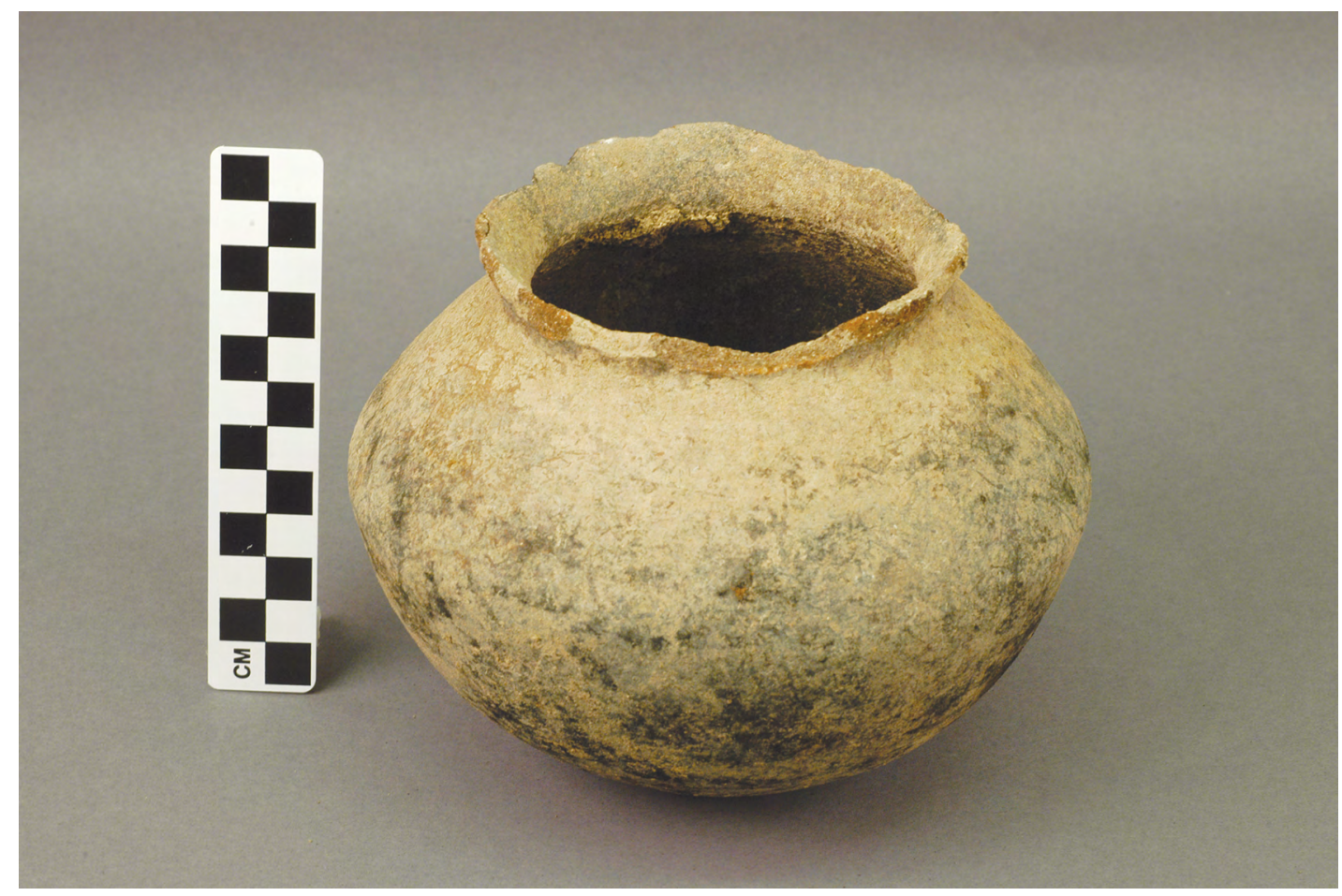

Figure 3.6. Earthenware pot from Ira Ara Burial 1.

Source: Peter V. Lape. 


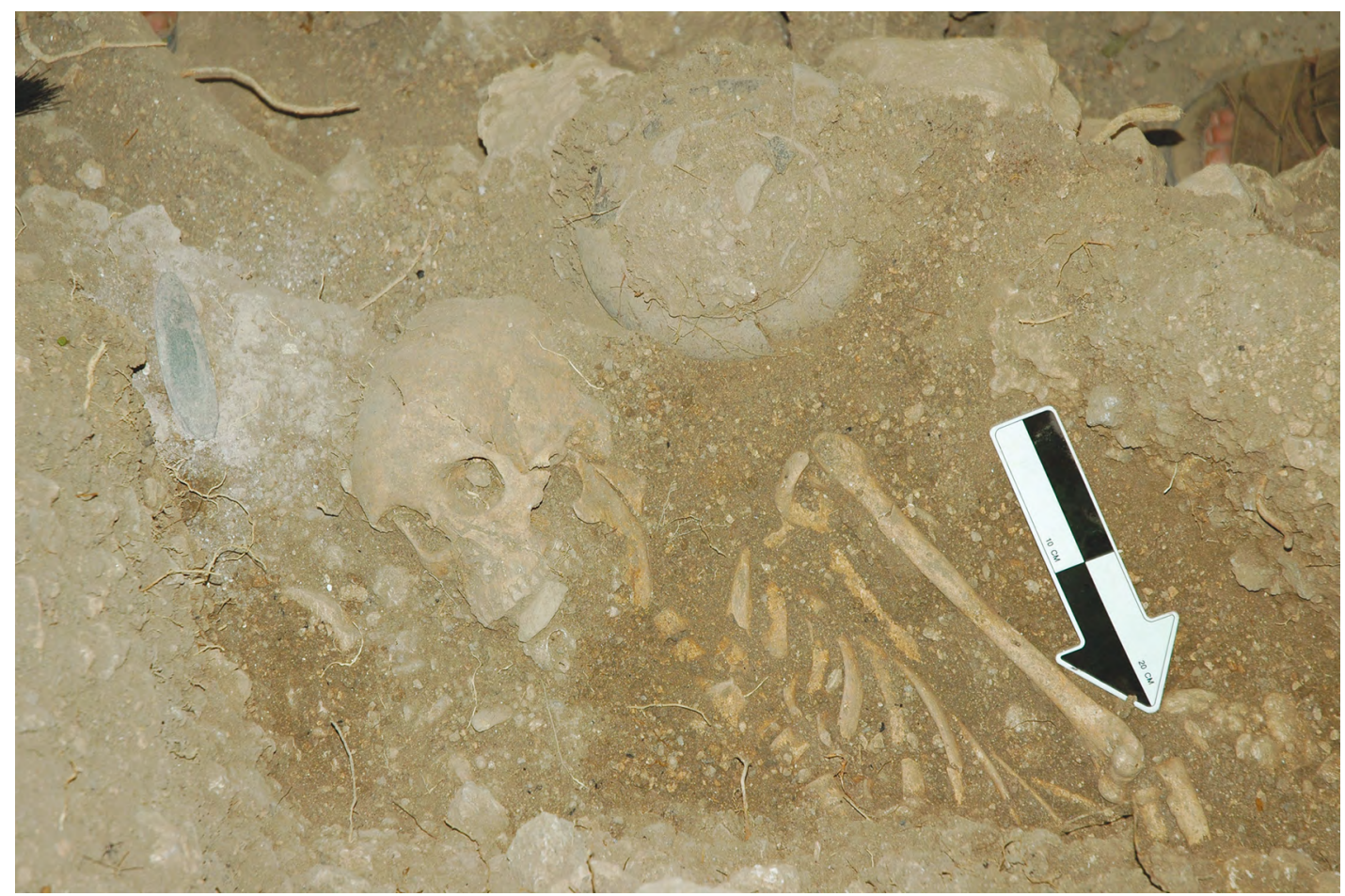

Figure 3.7. Ira Ara Burial 2 showing position of groundstone artefact and fragmented earthenware pot and lid.

The dog cranium was $3 \mathrm{~cm}$ above the chest area, and the dice were immediately adjacent to the groundstone artefact. Both were removed prior to this photo.

Source: Photo courtesy of Peter V. Lape.

The dice were six-sided and somewhat irregular in shape (Figure 3.8). They had unusual numbering, with four through eight pips, plus eight and nine (missing the five and six pips present on standard dice). Local informants were unfamiliar with this type of dice, and we have been unable to find similarly numbered examples of dice in the published literature. The cranium of a dog (Canis familiaris) was located above the chest area, presumably buried with this individual. No post-cranial dog remains were recovered and no other grave goods were found in this burial, though

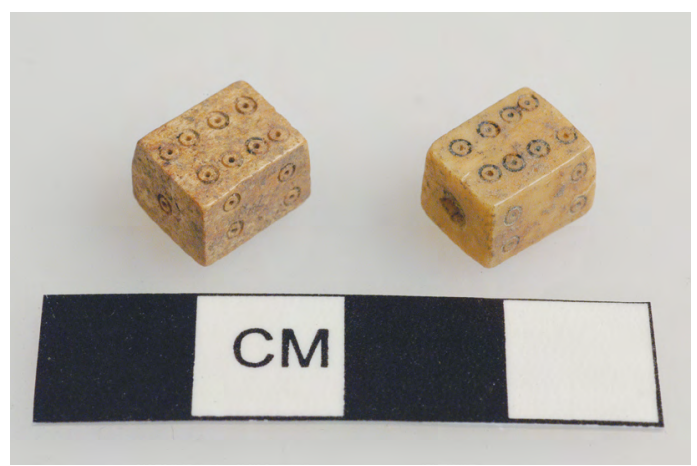

Figure 3.8. Dice from Ira Ara Burial 2.

Source: Peter V. Lape. it should be noted that we were only able to excavate to the bottom of the stone-lined grave pit in the area associated with the cranium of Burial 2. 


\section{Fauna}

Excavations at Ira Ara did not expose well-stratified undisturbed cultural deposits, and animal bones recovered were generally poorly preserved and fragmentary. Results presented here therefore represent the presence of animal species from mixed stratigraphic contexts representing several thousand years of human use of the site. As such, our analysis simply shows animal species present in the assemblage. A total of 309 bones were analysed from all three excavation pits, of which 206 were identified to family level or better (Table 3.2). Animal taxa present at Ira Ara include several human introductions, some thought to be quite recent. Conspicuously absent were rat and bat species, which are prevalent in other Timorese sites, though this may be simply a result of a small and poorly preserved faunal sample.

Table 3.2. Vertebrate fauna from Ira Ara, Units 1, 2 and 3.

\begin{tabular}{|l|c|c|}
\hline Taxon & Present & Absent \\
\hline Phalanger orientalis & $\mathrm{x}$ & - \\
\hline Sus scrofa & $\mathrm{x}$ & - \\
\hline Galliformes & $\mathrm{x}$ & - \\
\hline Cervus timorensis & $\mathrm{x}$ & - \\
\hline Capra hircus & $\mathrm{x}$ & - \\
\hline Canis familiaris & $\mathrm{x}$ & - \\
\hline Paradoxurus herphroditus & $\mathrm{x}$ & - \\
\hline Bos taurus & $\mathrm{x}$ & - \\
\hline Bubalus bubalis & $\mathrm{x}$ & - \\
\hline Equus & $\mathrm{x}$ & - \\
\hline Fish & $\mathrm{x}$ & - \\
\hline Felis silvestris & $\mathrm{x}$ & - \\
\hline Rattus exulans & - & $\mathrm{x}$ \\
\hline Mega and Microchiroptera & - & $\mathrm{x}$ \\
\hline Macaca fascicularis & - & $\mathrm{x}$ \\
\hline
\end{tabular}

Source: Authors' summary.

With respect to invertebrate remains, shellfish were also represented in all excavation units. However, only the shell from Unit 1 was analysed, since Unit 1 appeared to have less chance of mixed deposit than lower Layers 3 and 4, which had been disturbed by the two burials. Although Unit 1 was not directly dated, the presence of small amounts of tradeware in the Unit 1 context suggest a post-AD 1200 age for this deposit.

A total of 562 marine shell specimens were recovered from this unit, of which 216 were identifiable to at least the family level (Table 3.3). Although sample size is quite small, there is considerable diversity in the molluscan faunal assemblage. The 216 identified specimens represent 16 families, 19 genera and 20 species, forming a range of taxa from an intertidal reef flat. The most abundant taxa include Rochia nilotica, Turbo sp., Tridacna sp., Trochus maculatus, Cypraea spp., Hippopus hippopus and Conomurex luhuanus, and these large bivalves and gastropods dominate the assemblage. Four families, Trochidae, Tegulidae, Turbinidae and Tridacnidae, together account for 65 per cent of the identified specimens.

The abundance of these large-bodied, high-ranked taxa indicates that the occupants of Ira Ara had access to a rich coral reef patch for foraging. The same taxa are also abundant in many shell assemblages at other Timor-Leste sites, including both fortified hilltop settlements of similar age in the Manatuto region (Chao 2008), and cave sites in Tutuala (O'Connor et al. 2002) and Baucau (E. Glover 1986; I. Glover 1986), with evidence for occupation since the terminal 
Pleistocene or early Holocene. Due to the mixed nature of the deposits and small sample size, little can be said about diachronic patterning in shellfish use at Ira Ara itself, but qualitative similarity between this assemblage and those from much older prehistoric sites is consistent with the pattern observed by both Emily Glover (1986) and O'Connor et al. (2002): that there is very little evidence for change over time in the availability and exploitation of coral reef habitats in Timor-Leste.

Table 3.3. Molluscan fauna from the Ira Ara site, Unit 1.

\begin{tabular}{|c|c|c|}
\hline Taxon & NISP & $\%$ \\
\hline \multicolumn{3}{|l|}{ GASTROPODA } \\
\hline \multicolumn{3}{|l|}{ HALIOTIDAE } \\
\hline Haliotis sp. & 5 & 2.3 \\
\hline \multicolumn{3}{|l|}{ TROCHIDAE } \\
\hline Trochus maculatus & 19 & 8.8 \\
\hline Trochus sp. & 11 & 5.1 \\
\hline \multicolumn{3}{|l|}{ TEGULIDAE } \\
\hline Rochia nilotica & 30 & 13.9 \\
\hline \multicolumn{3}{|l|}{ TURBINIDAE } \\
\hline Turbo chrysostomus & 5 & 2.3 \\
\hline Turbo setosus & 4 & 1.9 \\
\hline Turbo spp. & 23 & 10.6 \\
\hline \multicolumn{3}{|l|}{ HIPPONICIDAE } \\
\hline fam. Hipponicidae & 3 & 1.4 \\
\hline \multicolumn{3}{|l|}{ NERITIDAE } \\
\hline Nerita costata & 3 & 1.4 \\
\hline Nerita polita & 5 & 2.3 \\
\hline Nerita undata & 3 & 1.4 \\
\hline \multicolumn{3}{|l|}{ STROMBIDAE } \\
\hline Conomurex luhuanus & 13 & 6.0 \\
\hline \multicolumn{3}{|l|}{ CYPRAEIDAE } \\
\hline Сургаеа spp. & 15 & 6.9 \\
\hline \multicolumn{3}{|l|}{ MITRIDAE } \\
\hline \multicolumn{3}{|l|}{ VOLUTIDAE } \\
\hline fam. Volutidae & 4 & 1.9 \\
\hline \multicolumn{3}{|l|}{ CONIDAE } \\
\hline Conus litteratus & 3 & 1.4 \\
\hline Conus spp. & 5 & 2.3 \\
\hline \multicolumn{3}{|l|}{ BIVALVIA } \\
\hline \multicolumn{3}{|l|}{ TRIDACNIDAE } \\
\hline Hippopus hippopus & 15 & 6.9 \\
\hline Tridacna crocea & 3 & 1.4 \\
\hline Tridacna maxima & 8 & 3.7 \\
\hline Tridacna sp. & 20 & 9.3 \\
\hline
\end{tabular}

Taxa representing < $1 \%$ of the total assemblage are omitted. These include: Angaria delphinus, Turbo bruneus, Nerita albicilla, Nerita plicata, Nerita sp., Lambis lambis, Strombus sp., Naticidae, Nassarius sp., Fasciolaridae, Mitra mitra, Conus marmoreus, Terebridae and Polyplacophora.

NISP: Number of individual specimens.

Source: Authors' summary. 


\section{Lithic artefacts}

Timor is located in an area heavily trafficked by various long-distance traders and has been part of the greater Indian and Chinese trade patterns since AD 100-200 (Chao 2008; Lape 2000; Reid 1993). This incorporation into a world economy brought major changes to the material culture of Timor, including a replacement of lithic artefacts with those of metal. The accepted date for the introduction of metal to Timor is also around $2000 \mathrm{BP}$ (I. Glover 1986:203). Ian Glover (1986:202) notes: 'Flint is used occasionally for strike-alights in Timor today and ... was abandoned as an important tool-making material at least 2000 years ago'. It was therefore unexpected to find chipped stone artefacts (except for strike-a-lights) at Ira Ara, given the probable seventeenth-century AD date of the burials. However, 186 lithic artefacts were recovered from the three excavation pits, representing a variety of artefact types; only two of these artefacts showed evidence of use as strike-alights (Figures 3.9, 3.10).

The majority of these artefacts are made of chert, a material locally present in cobble form. No obsidian artefacts were present, though they show up in older cave assemblages in the Lautem area (Ambrose et al. 2009). This collection of tools and debitage shows great similarity to the assemblages described by Ian Glover (1986; Ellen and Glover 1974) as Neolithic. He divides flakes with secondary working into six categories: tanged points, side scrapers, other scrapers, flaked adzes, burins and miscellaneous (1986:34). While no tanged points or flaked adzes were identified in the Ira Ara site, the remaining artefact types were present here. In addition, Ira Ara contained notched and tipped flakes; Ian Glover places notched tools in the 'scraper' category. He believes it is:

most probable that these artefacts were woodworking tools. The fact that so many are notched suggests that they were used for small, cylindrical objects such as digging sticks, bows, spears, or blow guns. (I. Glover 1986:35)
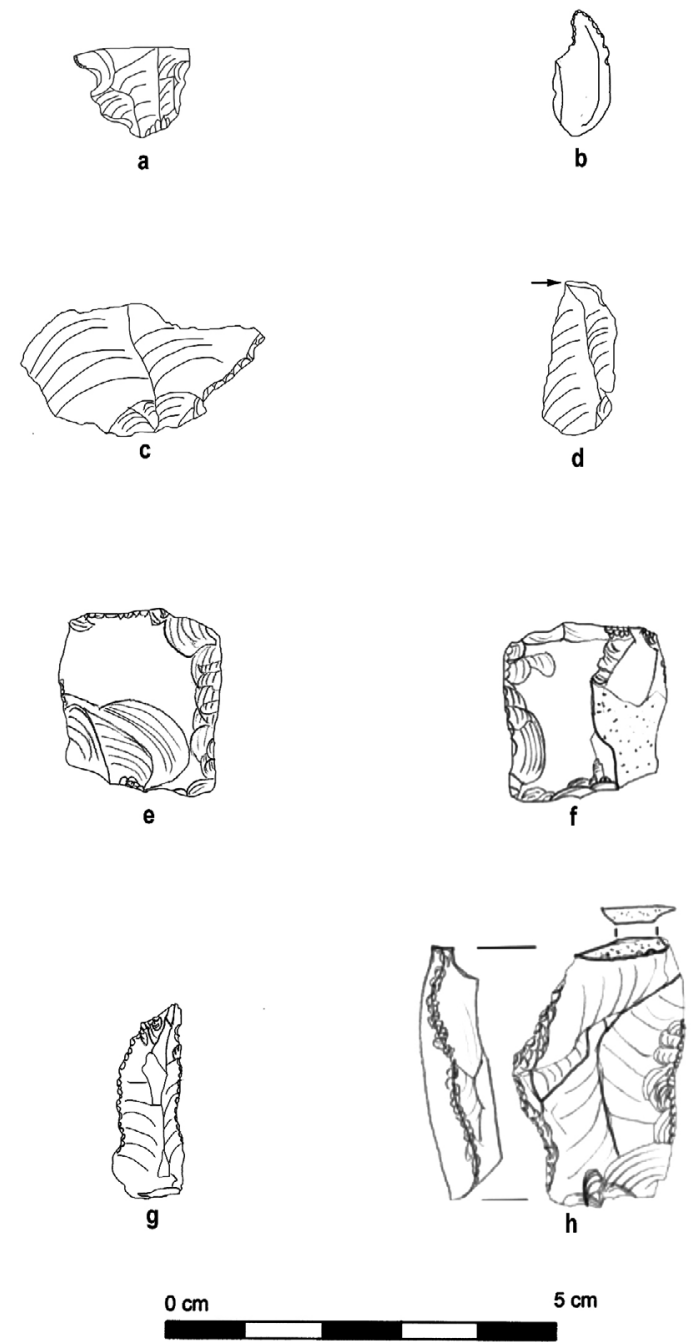

Figure 3.9. Selected lithic artefacts from Ira Ara.

A: Retouched flake with notch and tip (0102183400); B: Retouched flake with tip (022A036800a); C: Retouched flake with tip (022A033800e); D: Burin (02B2043800d); E: Flake scraper, ventral view (022B043800a); F: Flake scraper, dorsal view (022B043800a); G: Retouched flake (001133400); $\mathrm{H}$ : Core used as 'strike-a-light' (00000003510).

Source: Peter V. Lape. 


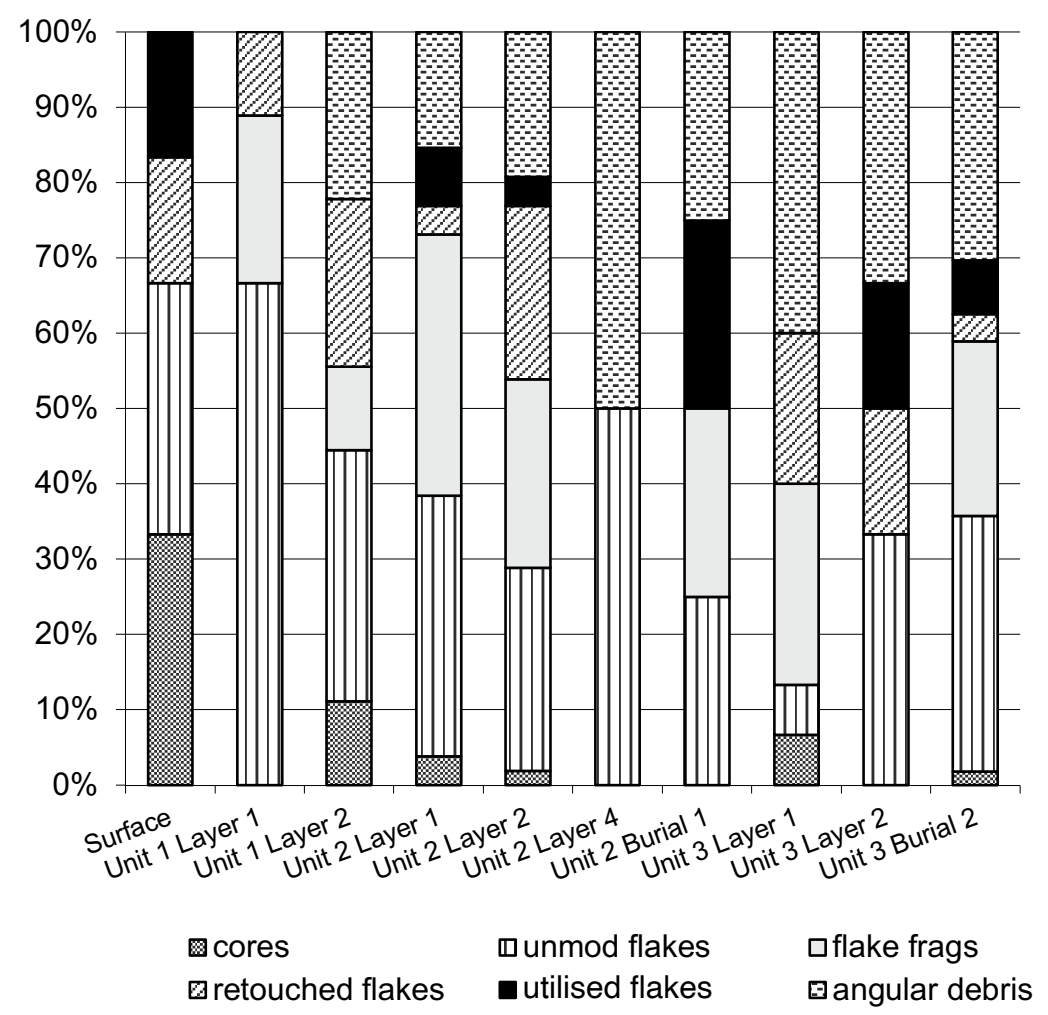

Figure 3.10. Relative frequency of lithic artefact types from Ira Ara.

Source: Authors' summary.

The lithic artefacts do not appear to have a random distribution throughout the different units, with 87 per cent of all artefacts found in the burial fill. The similar distribution of artefacts between the two burials may indicate that they were buried at about the same time or, more likely, the lithic assemblages are from earlier occupations that eroded from higher elevations on the mound and/or were mixed from deeper layers into the burial fill during inhumation.

\section{Discussion}

The Ira Ara site adds important new information about fortified settlements in Timor-Leste, and particularly about seventeenth-century AD burial practices. It does not allow conclusive testing of the resource-dependent model for initial fortification building as described in Lape and Chao (2008). To adequately test that model, a complete survey of fortified settlements in the Ira Ara region would need to be completed, with each site's initial fortification building episode securely dated. The earliest sites should date to times of increasing drought frequency and be located at the boundary of resource-rich and resource-poor areas. We would expect the Ira Ara site to be one of these earliest sites, given its location next to a large permanent water source in an otherwise dry area. Local informants recall that this spring has always flowed, even during severe droughts such as those experienced during major El Niño events in 1982-83 and 1997-98. Dates for the initial wall building at Ira Ara must be prior to the burials and after the deposition of Layer 4 (between $3800 \mathrm{cal} \mathrm{BP}$ and $500 \mathrm{cal} \mathrm{BP}$ ). Without further excavation, it is impossible to date the initial wall building more precisely, and thus the model cannot yet be tested. Dating the fortified period at Ira Ara is complicated by occupation and use of the site in the mid-Holocene, prior to fortification building. Future excavations at the site should focus on narrowing this date range 
by excavating in areas of non-burial disturbance to find the Layer $2 / 3$ interface, or by dating material immediately under the lowest course of limestone rocks used to build the walls, in the few areas not yet destroyed by recent activity.

The faunal and lithic assemblages are difficult to interpret, given that most were from burial fill and thus are likely from mixed contexts. Intriguing results that call for further examination are the lack of rats and bats in the fauna, and the presence of a diverse range of lithic artefacts. Neither would be expected in intact second millennium AD assemblages, but both are probably the result of stratigraphic disturbance and taphonomic processes.

Burial practices at the site are similar to metal age burials in other parts of Island Southeast Asia, with the presence of lidded pots, grave goods and jewellery. Notably absent are beads and tradeware vessels, which are common in many late metal age burials in the region (cf. Bellwood 1997). Many late Neolithic and early metal age burials in Indonesia and the Philippines are jar burials, though this practice may have changed in the later metal age, perhaps replaced by sacrificial animal burial in smaller jars as seen in Burial 1 (Simanjuntak et al. 2006). Local informants reported ongoing or remembered traditions of burying the dead with an offering of rice and baby chickens in small pots. Analyses of a small and fragmentary sample of human bone limits our ability to draw large conclusions. However, results from isotopic analysis show the probable inclusion of $\mathrm{C} 4$ plants, most likely millet, in the local diet. This might be the result of large-scale forest clearance and reliance on millet as a substitute perhaps for rice by the seventeenth century. This pattern of subsistence might be expected for people relying on a mix of marine and agricultural resources and calls for further research into palaeoenvironmental conditions and subsistence practices during this time period.

\section{Acknowledgements}

The authors wish to thank the following institutions and individuals for their contributions: Ministerio da Educacao, Cultura, Juventude e Desporto, Timor-Leste, Dr Armindo Maia, Virgilio Simith, Cecila Assis, Abílio da Conceição Silva, Horacio da Costa, the Xefe de Suco, ratu leaders and people of Ira Ara and Moro villages, Nuno Vasco Oliveira, Sue O'Connor, Sally Brockwell, Andrew McWilliam, Sandra Pannell, Chin-yung Chao, James Taylor, Robert Wood, Brooke Avery, Randy Hert, Kass Bessert and two anonymous reviewers. Thanks also to Richard Willan (Museum and Art Gallery of the Northern Territory) who updated the section on molluscan fauna.

\section{References}

Ambrose, S.H., B.M. Butler, D.B. Hanson, R.L Hunter-Anderson and H.W. Krueger 1997. Stable isotopic analysis of human diet in the Marianas Archipelago, Western Pacific. American Journal of Physical Anthropology 104(3):343-361. doi.org/10.1002/(sici)1096-8644(199711)104:3<343::aidajpa5>3.0.co;2-w.

Ambrose, W., C. Allen, S. O'Connor, M. Spriggs, N. Oliveira and C. Reepmeyer 2009. Possible obsidian sources for artefacts from Timor: Narrowing the options using chemical data. Journal of Archaeological Science 36(3):607-615. doi.org/10.1016/j.jas.2008.09.022.

Bass, W.M. 2005. Human osteology: A laboratory and field manual. 5th edition. Missouri Archaeological Society, Columbia.

Bellwood, P. 1997. Prehistory of the Indo-Malaysian Archipelago. University of Hawai'i Press, Honolulu. 
Buikstra, J.E. and D.H. Ubelaker (eds) 1994. Standards for data collection from human skeletal remains. Arkansas Archeology Survey Research Series 44. Fayetteville Arkansas Archeological Survey, Fayetteville.

Chao, C.-Y. 2008. A microregional approach to the social dynamics in the late prehistoric Manatuto, East Timor, 11th-18th century. Unpublished PhD thesis. University of Washington, Seattle.

Ellen, R.F. and I.C. Glover 1974. Pottery manufacture and trade in the Central Moluccas: The modern situation and the historical implications. Man (n.s.) 9:353-379. doi.org/10.2307/2800690.

Field, J. and P. Lape 2010. Paleoclimates and the emergence of fortifications in the tropical Pacific islands. Journal of Anthropological Archaeology 29:113-124. doi.org/10.1016/j.jaa.2009.11.001.

Fitzpatrick, D. 2002. Land claims in East Timor. Asia Pacific Press, Canberra.

Fitzpatrick, D. 2010. The relative resilience of property: First possession and order without law in East Timor. Law and Society Review 44(2):205-238. doi.org/10.1111/j.1540-5893.2010.00402.x.

Glover, E. 1986. Prehistoric utilisation of tropical reef molluscs in East Timor, Indonesia. Journal of Conchology 32:151-165.

Glover, I. 1986. Archaeology in Eastern Timor, 1966-67. Terra Australis 11. Department of Prehistory, Research School of Pacific Studies, The Australian National University, Canberra.

Lape, P.V. 2000. Contact and colonialism in the Banda Islands, Maluku, Indonesia. Bulletin of the IndoPacific Prehistory Association 20:48-55.

Lape, P.V. 2006. Chronology of fortified settlements in East Timor. Journal of Island and Coastal Archaeology 1(2):285-297. doi.org/10.1080/15564890600939409.

Lape, P.V. and C.-Y. Chao 2008. Fortification as a human response to late Holocene climate change in East Timor. Archaeology in Oceania 43(1):11-21. doi.org/10.1002/j.1834-4453.2008.tb00026.x.

Lape, P.V., S. O'Connor and N. Burningham 2007. Rock art: A potential source of information about past maritime technology in the Southeast Asia-Pacific region. International Journal of Nautical Archaeology 36(2):238-253. doi.org/10.1111/j.1095-9270.2006.00135.x.

McWilliam, A. 2007a. Austronesians in linguistic disguise: Fataluku cultural fusion in East Timor. Journal of Southeast Asian Studies 38(2):355-375. doi.org/10.1017/s0022463407000082.

McWilliam, A. 2007b. Harbouring traditions in East Timor: Marginality in a lowland entrepôt. Modern Asian Studies 41(6):1113-1143. doi.org/10.1017/s0026749x07002843.

McWilliam, A. 2007c. Looking for Adê: A contribution to Timorese historiography. Bijdragen tot de Taal-, Land-en Volkenkunde 163(2/3):221-238. doi.org/10.1163/22134379-90003684.

McWilliam, A. 2008. Fataluku healing and cultural resilience in East Timor. Ethnos 73(2):217-240. doi.org/10.1080/00141840802180371.

O'Connor, S. 2003. Nine new painted rock art sites from East Timor in the context of the Western Pacific region. Asian Perspectives 42(1):96-128. doi.org/10.1353/asi.2003.0028.

O'Connor, S. 2007. New evidence from East Timor contributes to our understanding of earliest modern human colonisation east of the Sunda Shelf. Antiquity 81:523-555. doi.org/10.1017/ s0003598x00095569.

O'Connor, S. and N. Oliveira 2007. Inter- and intra-regional variation in the Austronesian painting tradition: A view from East Timor. Asian Perspectives 46(2):389-403. doi.org/10.1353/ asi.2007.0014. 
O’Connor, S., M. Spriggs and P. Veth 2002. Excavation at Lene Hara Cave establishes occupation in East Timor at least 30,000-35,000 years ago. Antiquity 76:45-50. doi.org/10.1017/ s0003598x0008978x.

Pannell, S. 2006. Welcome to the Hotel Tutuala: Fataluku accounts of going places in an immobile world. The Asia Pacific Journal of Anthropology 7(3):203-219. doi.org/10.1080/14442210600965158.

Pannell, S. and S. O'Connor 2005. Toward a cultural topography of cave use in East Timor: A preliminary study. Asian Perspectives 44(1):193-206. doi.org/10.1353/asi.2005.0011.

Reid, A. (ed.) 1993. Southeast Asia in the early modern era: Trade, power, and belief. Cornell University Press, Ithaca.

Simanjuntak, T., M. Hisyam, B. Praesyo and T.S. Astiti (eds) 2006. Archaeology: Indonesian perspective: R.P. Soejono's festschrift. International Center for Prehistoric and Austronesian Studies, Indonesian Institute of Sciences, Menteng, Jakarta.

Spriggs, M. 2000. Out of Asia: The spread of Southeast Asian Pleistocene and Neolithic maritime cultures in Island Southeast Asia and the Western Pacific. Modern Quaternary Research in Southeast Asia 16(V-VI):51-76.

Spriggs, M. 2003. Chronology of the Neolithic transition in Island Southeast Asia and the Western Pacific: A view from 2003. The Review of Archaeology 24(2):57-80.

Spriggs, M., S. O'Connor and P. Veth 2003. Vestiges of early pre-agricultural economy in the landscape of East Timor: Recent research. In A. Källén and A. Karlström (eds), Fishbones and glittering emblems: Proceedings from the EurASEEA Sigtuna Conference, pp. 49-58. Museum of Far Eastern Antiquities, Stockholm.

Veth, P., M. Spriggs and S. O'Connor 2005. Continuity in tropical cave use: Examples from East Timor and the Aru Islands, Maluku. Asian Perspectives 44(1):180-192. doi.org/10.1353/asi.2005.0015. 
This text is taken from Forts and Fortification in Wallacea: Archaeological and Ethnohistoric Investigations, edited by Sue O'Connor, Andrew McWilliam and Sally Brockwell, published 2020 by ANU Press, The Australian National University, Canberra, Australia.

doi.org/10.22459/TA53.2020.03 